BMJ Open Diabetes

Research \& Care

\title{
Incidence and risk factors for mortality and end-stage renal disease in people with type 2 diabetes and diabetic kidney disease: a population-based cohort study in the UK
}

\author{
Antonio González-Pérez (D) , ${ }^{1,2}$ Maria Saez, ${ }^{1,2}$ David Vizcaya, ${ }^{3}$ Marcus Lind, ${ }^{4}$ \\ Luis Garcia Rodriguez ${ }^{1}$
}

To cite: González-Pérez A, Saez M, Vizcaya D, et al. Incidence and risk factors for mortality and end-stage renal disease in people with type 2 diabetes and diabetic kidney disease: a populationbased cohort study in the UK. BMJ Open Diab Res Care 2021;9:e002146. doi:10.1136/ bmjdrc-2021-002146

- Additional supplemental material is published online only. To view, please visit the journal online (http://dx.doi. org/10.1136/bmjdrc-2021002146).

Received 18 January 2021 Accepted 14 September 2021

Check for updates

(C) Author(s) (or their employer(s)) 2021. Re-use permitted under CC BY-NC. No commercial re-use. See rights and permissions. Published by BMJ.

${ }^{1}$ Spanish Centre for Pharmacoepidemiologic Research (CEIFE), Madrid, Spain

${ }^{2}$ Andalusian Bioinformatics Research Centre (CAEBi), Seville, Spain ${ }^{3}$ Epidemiology, Bayer Hispania, Barcelona, Spain

${ }^{4}$ Institute of Medicine, University of Gothenburg, Uddevalla, Sweden

Correspondence to Dr Antonio González-Pérez; agonzalez@ceife.es

\section{ABSTRACT}

Introduction We aimed to determine the incidence of, and risk factors for all-cause/cardiovascular disease (CVD) mortality, and end-stage renal disease (ESRD) among people with type 2 diabetes with/without diabetic kidney disease (DKD) in the UK general population.

Research design and methods We undertook a population-based cohort study using primary care UK electronic health records. We followed 8413 people with type 2 diabetes and DKD and a matched comparison cohort of people with type 2 diabetes without DKD. Risk factors for all-cause/CVD mortality (using both cohorts) and ESRD (DKD cohort only) were evaluated by estimating HRs with $95 \%$ Cls using Cox regression.

Results In the DKD cohort (mean age 66.7 years, $62.4 \%$ male), incidence rates per 1000 person-years were 50.3 (all-cause mortality), 8.0 (CVD mortality) and 6.9 (ESRD). HRs (95\% Cls; DKD vs comparison cohort) were 1.49 (1.35 to 1.64) for all-cause mortality and 1.60 (1.24 to 2.05) for CVD mortality. In general, higher all-cause mortality risks were seen with older age, underweight (body mass index $<20 \mathrm{~kg} / \mathrm{m}^{2}$ ), reduced renal function, and cardiovascular/ liver disease, and lower risks were seen with being female or overweight. In the DKD cohort, higher risks of ESRD were seen with reduced renal function at baseline, high material deprivation, cancer and non-insulin glucoselowering drugs, and a lower risk was seen with overweight $\left(\geq 25 \mathrm{~kg} / \mathrm{m}^{2}\right)$.

Conclusions Annually, one death will occur among every 20 people with type 2 diabetes and DKD. The identified risk factors in this study will help identify people with type 2 diabetes at most risk of death and progression of kidney disease, and help to direct effective management strategies.

\section{INTRODUCTION}

The global prevalence of diabetes continues to increase with projections of a rise from $9.3 \%$ in 2019 to $10.9 \%$ by 2045 , largely driven by ageing populations and lifestyle changes. ${ }^{1}$ About $30 \%-40 \%$ of people with diabetes will develop diabetic kidney disease $(\mathrm{DKD})^{2}{ }^{3}$ kidney disease caused by diabetes itself, and

\begin{tabular}{|c|}
\hline SIGNIFICANCE OF THIS STUDY \\
\hline $\begin{array}{l}\text { WHAT IS ALREADY KNOWN ABOUT THIS } \\
\text { SUBJECT? }\end{array}$ \\
\hline $\begin{array}{l}\Rightarrow \text { Reductions in the proportion of people with diabetic } \\
\text { kidney disease (DKD) progressing to end-stage re- } \\
\text { nal disease (ESRD) have been small, and mortality } \\
\text { among people with DKD remains strikingly high. }\end{array}$ \\
\hline WHAT ARE THE NEW FINDINGS? \\
\hline $\begin{aligned} & \Rightarrow \text { In people with type } 2 \text { diabetes and DKD, reduced } \\
& \text { renal function, high material deprivation, cancer and } \\
& \text { non-insulin glucose-lowering drugs were associated } \\
& \text { with a higher ESRD risk. } \\
& \Rightarrow \text { Being overweight could confer a lower ESRD risk, al- } \\
& \text { though this result should be interpreted with caution. } \\
& \Rightarrow \text { Our results highlight the importance of screening for } \\
& \text { the presence of DKD in primary care. }\end{aligned}$ \\
\hline $\begin{array}{l}\text { HOW MIGHT THESE RESULTS CHANGE THE } \\
\text { FOCUS OF RESEARCH OR CLINICAL PRACTICE? }\end{array}$ \\
\hline $\begin{array}{l}\Rightarrow \text { The identified risk factors in this study will help iden- } \\
\text { tify people with type } 2 \text { diabetes at most risk of death } \\
\text { and progression of kidney disease and help to direct } \\
\text { effective management strategies. } \\
\Rightarrow \text { Reduction of all-cause mortality observed with the } \\
\text { use of glucagon-like peptide- } 1 \text { receptor agonists } \\
\text { should be further investigated in randomized con- } \\
\text { trolled trials. }\end{array}$ \\
\hline
\end{tabular}

the leading cause of overall chronic kidney disease (CKD).$^{45}$ In addition, about $30 \%$ of people with type 2 diabetes will progress to end-stage renal disease (ESRD), ${ }^{6}$ and renal replacement therapy among these persons estimated to account for $3 \%-5 \%$ of national European healthcare budgets. ${ }^{7}$

Cardiovascular (CV) complications are a major cause of mortality in people with diabetes, and those with DKD have a particularly high risk of these complications. 
Ten-year cumulative all-cause mortality in people with diabetes and CKD has been estimated to be $31.1 \%$, compared with $11.5 \%$ in people with diabetes but without CKD, and $7.7 \%$ in people without either condition. ${ }^{8}$ There is mounting evidence that people with DKD face an increased risk of death, ${ }^{9}$ which does not seem to depend on the DKD subphenotype. ${ }^{10}$ While last two decades have seen a significant decline in the development of CV disease (CVD) and associated death among people with diabetes, reductions in progression to ESRD have been much smaller. ${ }^{11}$ Moreover, because of the high prevalence of diabetes, the burden of both diabetes-related CVD and renal complications remains high, ${ }^{12}$ and despite the effectiveness of current DKD management strategies, mortality among people with DKD remains strikingly high. ${ }^{13}$ Among the literature on this topic, relatively few studies have focused on the incidence and risk factors of major clinical outcomes specifically among the DKD population. There is therefore a need to better understand the epidemiology of $\mathrm{CV} /$ renal outcomes and mortality among this high-risk group of people with diabetes. We aimed to determine the incidence of, and risk factors for all-cause and CV mortality, and development of stage $5 \mathrm{CKD} / \mathrm{ESRD}$ in a population-based cohort study of people with type 2 diabetes with/without DKD.

\section{RESEARCH DESIGN AND METHODS}

\section{Study design and data source}

We conducted a population-based cohort study using data from the IQVIA Medical Research Data UK (IMRD-UK), formerly The Health Improvement Network. This study builds on previously published work, and information on the IMRD-UK, the source population, inclusion criteria, DKD/CKD definitions and protocol approval can be found elsewhere. ${ }^{14}$ Briefly, between January 1, 2002 and December 31, 2014, 114056 individuals without CKD and with newly diagnosed diabetes were followed and incident cases of CKD and DKD (defined using the Kidney Disease Outcomes Quality Initiative (KDOQI) clinical criteria) ${ }^{15}$ and CKD were identified. Thus, individuals with DKD included those with a specific DKD diagnostic code recorded in the database, those with at least two albumin-to-creatinine ratio (ACR) measurements greater than $300 \mathrm{mg} / \mathrm{g}$ (recorded more than 90 days apart), and also those with CKD (two or more measurements of estimated glomerular filtration rate (eGFR) below $60 \mathrm{~mL} /$ $\min / 1.73 \mathrm{~m}^{2}$ more than 90 days apart) with evidence of proteinuria (ACR greater than $30 \mathrm{mg} / \mathrm{g}$, albuminuria greater than $20 \mathrm{mg} / \mathrm{L}$, or proteinuria diagnostic code). In this current study, we followed up the incident cases DKD with type 2 diabetes and a matched comparison cohort of people with diabetes without DKD to determine the incidence of, and risk factors, for all-cause/CV mortality, and followed the DKD cohort separately for development of stage $5 \mathrm{CKD} / \mathrm{ESRD}$.

\section{DKD and non-DKD comparison cohort}

The study entry date for this present study was the date of DKD onset. To establish a comparison cohort of people with type 2 diabetes but without DKD, we matched each member of the DKD cohort 1:1 to a randomly selected individual free of DKD on the date of diabetes diagnosis, and of the same sex, age, type of diabetes and year of diabetes onset. Once selected, people in the comparison cohort entered the study on the same date as their matched partner. As the sequential random sampling process to select individuals in the comparison cohort was performed without replacement, individuals in a matched pair were no longer eligible to become part of a future matched pair. This method avoided selection bias that can be introduced when using information on future events to obtain cohorts, although it resulted in a smaller cohort than would have been identified otherwise. After this process, there were 8416 members of the DKD cohort matched to an equal number of individuals in the comparison cohort; 10 individuals in total were $<18$ years of age.

\section{Follow-up to mortality outcomes}

We followed up the DKD and comparison cohorts from study entry until death or the end of follow-up (December 31, 2015), whichever came first. Deaths due to CVD were ascertained by entries for CVD as the reported cause of death or, if this was missing, by recorded entries for at least one of the following in the 90 days before the date of death (in the absence of a record of cancer in the year before the date of death): ischemic heart disease, cardiac surgery, heart failure, and cerebrovascular disease. For these people, we subsequently manually reviewed their electronic primary care record to confirm whether their death was $\mathrm{CV}$ related or non-CV related.

\section{Follow-up to identify stage 5 CKD/ESRD}

In a separate follow-up of the DKD cohort, we identified those with a coded entry for stage 5 CKD/ESRD during their period of observation, that is, follow-up ended at the date of stage $5 \mathrm{CKD} / \mathrm{ESRD}$, death or the end of the study period, whichever came first. After excluding people already classified as stage $5 \mathrm{CKD} / \mathrm{ESRD}$ on the date of first DKD diagnosis (ie, prevalent cases), 9175 people remained eligible for this follow-up. We defined stage 5 CKD as a recorded eGFR of $<15 \mathrm{~mL} / \mathrm{min} / 1.73 \mathrm{~m}^{2}$, and ESRD as a coded entry of dialysis or kidney transplant.

\section{Covariates}

We extracted information from the database on person demographics (including the Townsend material deprivation score) ${ }^{16}$ comorbidities, lifestyle factors, healthcare use and medication use. Details of these variables have been described previously. ${ }^{14}$ For this present study, we determined comorbidities (including renal function, glycemic control and lifestyle factors) anytime before study entry using the most recent value/status for the latter. Codes used to identify comorbidities can be found 
in online supplemental tables 1-11. Healthcare use (general practitioner (GP) visits, referrals to secondary care, and hospitalizations) and medication use (including antidiabetic drugs) were determined from prescriptions issued in the year before study entry.

\section{Statistical analyses}

Crude incidence rates of all-cause mortality/CV mortality were calculated for the DKD and comparison cohorts by dividing the number of deaths/CV deaths by the respective total person-years follow-up. Crude incidence rates of stage $5 \mathrm{CKD} / \mathrm{ESRD}$ were calculated similarly for the DKD cohort. Incidence rates were stratified by age $(<65$ years and $\geq 65$ years) and sex. Associations between having DKD and all-cause mortality/CV mortality were estimated by calculating HRs with $95 \%$ CIs using multivariable Cox proportional hazard regression adjusted for confounders. Associations between other person characteristics, and all-cause mortality/CV mortality were also investigated. In the analysis of CV mortality and stage 5/ESRD, we used both Cox proportional hazard regression and Fine and Gray regression. ${ }^{17}$ The latter enables the estimation of subdistribution HRs accounting for competing risks from causes other than the cause being analyzed (ie, accounting for non-CV deaths in the CV mortality analysis, and accounting for all-cause death in the stage $5 \mathrm{CKD} / \mathrm{ESRD}$ analysis).

\section{RESULTS}

\section{All-cause mortality}

Baseline characteristics of the DKD and comparison are shown in table 1 for the cohort combined, and in online supplemental table 12 for the cohorts separately. The mean age of both cohorts was 66.7 years, and $62.4 \%$ were male. A total of 2266 people died during follow-up: 1465 in the DKD cohort over a mean follow-up of 3.5 years, and 801 in the comparison cohort over a mean follow-up of 3.4 years. The crude all-cause mortality rate in the DKD cohort was almost double the rate in the comparison cohort at start of follow-up (50.3 vs 28.4 per 1000 person-years). The corresponding crude HR (DKD vs comparison cohort) of 1.77 (95\% CI: 1.62 to 1.93 ) was slightly attenuated after adjusting for confounders; adjusted HR 1.49 (95\% CI: 1.35 to 1.64). Older age was strongly related to all-cause mortality; the mortality rate was 2.9 per 1000 person-years in people aged $<40$ years, increasing to 17.3 per 1000 person-years (for 50-64 years), and 91.4 per 1000 person-years (for 75-89 years). Compared with people aged 40-49 years, the risk of death was increased twofold in those aged 50-64 years, fourfold in those aged 65-74 years, and eightfold in those aged 75-89 years. Other variables strongly associated with a higher risk of all-cause mortality were smoking, being underweight (body mass index (BMI) $<20 \mathrm{~kg} / \mathrm{m}^{2}$ ), CVD, cerebrovascular disease, pancreatic disease, liver disorders, eGFR $<45 \mathrm{~mL} / \mathrm{min} / 1.73 \mathrm{~m}^{2}$, use of mineralocorticoid receptor antagonists (MRAs) in the year before study entry, and a high number of GP visits/at least one hospitalization in the year before study entry. We also found clear evidence that being female and being overweight were associated with a lower risk of all-cause mortality.

As shown in table 2, the higher risk of all-cause mortality associated with having DKD was broadly similar among people aged $<65$ years and $\geq 65$ years, and among males and females-the point estimates being higher among the younger age group and females. Reductions in allcause mortality were also seen with use of glucagon-like peptide-1 (GLP-1) receptor agonists (a 50\% lower risk of death, adjusted HR $0.51,95 \%$ CI: 0.27 to 0.95 ), and metformin (adjusted HR 0.90, 95\% CI: 0.83 to 0.99), while insulin was associated with a higher risk of death (adjusted HR 1.37, 95\% CI: 1.15 to 1.63) (online supplemental table 13).

\section{CV mortality}

Of the 2266 people who died during follow-up, 336 died from CVD (233 in the DKD cohort and 103 in the comparison cohort). The crude CV mortality rate in the DKD cohort was more than double the rate in the comparison cohort (8.0 vs 3.7 per 1000 person-years). Associations between person characteristics (DKD and comparison cohort combined) and CV mortality are shown in table 3 . The DKD cohort had a $60 \%$ higher risk of CV mortality compared with the comparison cohort when using either the Cox regression model (adjusted HR 1.60, 95\% CI: 1.24 to 2.05) or the Fine and Gray model (adjusted HR $1.56,95 \%$ CI: 1.21 to 2.00 ). Older age, a high level of material deprivation (Townsend index), hypertension, atrial fibrillation, cerebrovascular disease, reduced renal function (eGFR $<60 \mathrm{~mL} / \mathrm{min} / 1.73 \mathrm{~m}^{2}$ ), and a high level of GP visits/use of MRA in the year before DKD diagnosis were also strongly associated with higher risks of $\mathrm{CV}$ mortality. We found moderate evidence for a higher risk of CV mortality among people with glycemic control at $>8 \%$ during some point in the year before study entry, for heart failure, and for chronic obstructive pulmonary disease.

\section{Stage 5 CKD/ESRD among people with DKD}

Among 9175 people with type 2 diabetes and DKD without stage $5 \mathrm{CKD} / \mathrm{ESRD}$ at study entry, 213 developed stage $5 \mathrm{CKD} / \mathrm{ESRD}$ during follow-up; a crude incidence rate of 6.93 per 1000 person-years. Associations between person characteristics and risk of ESRD are shown in table 4 and online supplemental table 14 . We found strong evidence that higher level of material deprivation, cancer, reduced renal function $(<60 \mathrm{~mL} /$ $\min / 1.73 \mathrm{~m}^{2}$ ), a high level of GP visits, and use of oral antidiabetic drug use in the year before DKD diagnosis were associated with higher risks of developing stage 5 CKD/ESRD. Our results provided statistical evidence that being overweight was associated with a lower risk of developing stage 5 CKD/ESRD, although significance was not reached in the Fine and Gray analysis for those with a BMI of $\geq 30 \mathrm{~kg} / \mathrm{m}^{2}$. Further, subdividing individuals 
Table 1 HRs (95\% Cls) for the association between DKD, and other person characteristics, and risk of all-cause mortality among people with type 2 diabetes

\begin{tabular}{|c|c|c|c|c|c|c|}
\hline Variable & $\mathbf{N}$ & Deaths & Person-years & $\begin{array}{l}\text { Mortality rate per } \\
1000 \text { person-years }\end{array}$ & $\begin{array}{l}\mathrm{HR}^{\star} \\
(95 \% \mathrm{Cl})\end{array}$ & $P$ value \\
\hline \multicolumn{7}{|l|}{ Subcohort } \\
\hline Comparison & 8416 & 801 & 28222 & 28.4 & 1.0 (reference) & \\
\hline DKD & 8416 & 1465 & 29128 & 50.3 & 1.49 (1.35 to 1.64$)$ & $<0.01$ \\
\hline \multicolumn{7}{|l|}{ Age (years) } \\
\hline$<40$ & 282 & 3 & 1038 & 2.9 & 0.36 (0.11 to 1.18$)$ & 0.09 \\
\hline $40-49$ & 1240 & 32 & 4708 & 6.8 & 1.0 (reference) & \\
\hline $50-64$ & 5012 & 317 & 18326 & 17.3 & 2.29 (1.59 to 3.31$)$ & $<0.01$ \\
\hline $65-74$ & 5624 & 667 & 19631 & 34.0 & 4.02 (2.79 to 5.80$)$ & $<0.01$ \\
\hline $75-89$ & 4674 & 1247 & 13646 & 91.4 & $8.30(5.73$ to 12.01$)$ & $<0.01$ \\
\hline \multicolumn{7}{|l|}{ Sex } \\
\hline Male & 10502 & 1408 & 35478 & 39.7 & 1.0 (reference) & \\
\hline Female & 6330 & 858 & 21871 & 39.2 & 0.84 (0.77 to 0.92) & $<0.01$ \\
\hline \multicolumn{7}{|l|}{ Smoking } \\
\hline Non-smoker & 5434 & 536 & 19914 & 26.9 & 1.0 (reference) & \\
\hline Smoker & 2204 & 292 & 7487 & 39.0 & 1.62 (1.39 to 1.88$)$ & $<0.01$ \\
\hline Ex-smoker & 7450 & 1039 & 28048 & 37.0 & 1.07 (0.95 to 1.19$)$ & 0.26 \\
\hline Missing & 1744 & 399 & 1901 & 209.9 & 7.14 (6.22 to 8.20$)$ & $<0.01$ \\
\hline \multicolumn{7}{|l|}{ Alcohol (units/week) } \\
\hline Non-drinker & 3686 & 554 & 12341 & 44.9 & 1.0 (reference) & \\
\hline $1-2$ & 5528 & 676 & 18116 & 37.3 & 0.96 (0.85 to 1.08$)$ & 0.47 \\
\hline $3-15$ & 4198 & 537 & 14702 & 36.5 & $1.00(0.89$ to 1.14$)$ & 0.95 \\
\hline $16-24$ & 900 & 95 & 3211 & 29.6 & 0.89 (0.71 to 1.12$)$ & 0.33 \\
\hline$\geq 25$ & 1077 & 138 & 3719 & 37.1 & $1.16(0.95$ to 1.41$)$ & 0.14 \\
\hline Missing & 1443 & 266 & 5261 & 50.6 & 1.21 (1.04 to 1.41$)$ & 0.01 \\
\hline \multicolumn{7}{|l|}{$\mathrm{BMI}\left(\mathrm{kg} / \mathrm{m}^{2}\right)$} \\
\hline$<20$ & 271 & 112 & 730 & 153.4 & $1.60(1.30$ to 1.98$)$ & $<0.01$ \\
\hline $20-24$ & 2266 & 492 & 7282 & 67.6 & 1.0 (reference) & \\
\hline $25-29$ & 5622 & 749 & 19643 & 38.1 & 0.71 (0.63 to 0.80$)$ & $<0.01$ \\
\hline$\geq 30$ & 8560 & 873 & 29330 & 29.8 & 0.72 (0.64 to 0.81$)$ & $<0.01$ \\
\hline Missing & 113 & 40 & 364 & 109.8 & 1.79 (1.29 to 2.49$)$ & $<0.01$ \\
\hline \multicolumn{7}{|l|}{ Townsend index (quintile) } \\
\hline 1st (least deprivation) & 3396 & 412 & 11523 & 35.8 & 1.0 (reference) & \\
\hline 2nd & 3446 & 463 & 11578 & 40.0 & $1.03(0.90$ to 1.17$)$ & 0.70 \\
\hline $3 r d$ & 3549 & 481 & 12191 & 39.5 & $1.08(0.94$ to 1.23$)$ & 0.27 \\
\hline 4th & 3415 & 501 & 11797 & 42.5 & 1.10 (0.96 to 1.26$)$ & 0.16 \\
\hline 5th (most deprivation) & 2572 & 355 & 8836 & 40.2 & 1.07 (0.93 to 1.24$)$ & 0.35 \\
\hline Missing & 454 & 54 & 1424 & 37.9 & 0.94 (0.71 to 1.26$)$ & 0.69 \\
\hline \multicolumn{7}{|l|}{ Glycemic control quality $\dagger$} \\
\hline Always $\leq 8 \%$ & 10619 & 1462 & 36119 & 40.5 & 1.0 (reference) & \\
\hline At some point $>8 \%$ & 4359 & 478 & 13999 & 34.2 & 1.06 (0.95 to 1.18$)$ & 0.30 \\
\hline Missing & 1854 & 326 & 7232 & 45.1 & 1.14 (1.01 to 1.30$)$ & 0.04 \\
\hline \multicolumn{7}{|l|}{ Comorbidities } \\
\hline Hypertension & 11563 & 1639 & 39180 & 41.8 & 1.02 (0.92 to 1.13$)$ & 0.68 \\
\hline
\end{tabular}


Table 1 Continued

\begin{tabular}{|c|c|c|c|c|c|c|}
\hline Variable & $\mathbf{N}$ & Deaths & Person-years & $\begin{array}{l}\text { Mortality rate per } \\
1000 \text { person-years }\end{array}$ & $\begin{array}{l}\mathrm{HR}^{*} \\
(95 \% \mathrm{Cl})\end{array}$ & $P$ value \\
\hline Hyperlipemia & 5598 & 717 & 19176 & 37.4 & 0.90 (0.82 to 0.99$)$ & 0.03 \\
\hline Heart failure & 944 & 303 & 2573 & 117.8 & 1.33 (1.15 to 1.54$)$ & $<0.01$ \\
\hline IHD & 3455 & 693 & 11383 & 60.9 & 1.18 (1.07 to 1.30$)$ & $<0.01$ \\
\hline Atrial fibrillation & 1607 & 446 & 4632 & 96.3 & 1.24 (1.10 to 1.40$)$ & $<0.01$ \\
\hline Cerebrovascular disease & 1598 & 399 & 4857 & 82.2 & $1.35(1.21$ to 1.51$)$ & $<0.01$ \\
\hline COPD & 1466 & 356 & 4150 & 85.8 & 1.68 (1.49 to 1.89$)$ & $<0.01$ \\
\hline Peptic ulcer disease & 1286 & 242 & 4022 & 60.2 & 1.10 (0.96 to 1.26$)$ & 0.17 \\
\hline Pancreatic disease & 283 & 60 & 877 & 68.4 & 1.30 (1.01 to 1.69$)$ & 0.04 \\
\hline Liver disorders & 734 & 111 & 2074 & 53.5 & 1.36 (1.12 to 1.66$)$ & $<0.01$ \\
\hline Cancer & 2584 & 595 & 7384 & 80.6 & 1.61 (1.46 to 1.78$)$ & $<0.01$ \\
\hline \multicolumn{7}{|l|}{ GP visits† } \\
\hline$<12$ & 3619 & 343 & 13698 & 25.0 & 1.0 (reference) & \\
\hline $12-23$ & 7930 & 930 & 27879 & 33.4 & 1.21 (1.06 to 1.37$)$ & $<0.01$ \\
\hline $24-35$ & 3337 & 524 & 10655 & 49.2 & 1.27 (1.09 to 1.47$)$ & $<0.01$ \\
\hline$\geq 36$ & 1946 & 469 & 5117 & 91.7 & 1.81 (1.53 to 2.15$)$ & $<0.01$ \\
\hline \multicolumn{7}{|l|}{ Referrals to secondary care $†$} \\
\hline None & 2282 & 312 & 9292 & 33.6 & 1.0 (reference) & \\
\hline $1-6$ & 10079 & 1216 & 35216 & 34.5 & 0.94 (0.83 to 1.07$)$ & 0.39 \\
\hline$\geq 7$ & 4471 & 738 & 12842 & 57.5 & 0.98 (0.84 to 1.15$)$ & 0.83 \\
\hline$\geq 1$ hospitalization $†$ & 3176 & 627 & 9311 & 67.3 & $1.23(1.10$ to 1.36$)$ & $<0.01$ \\
\hline \multicolumn{7}{|c|}{ Lowest eGFR $\left(\mathrm{mL} / \mathrm{min} / 1.73 \mathrm{~m}^{2}\right) \dagger$} \\
\hline$\geq 90$ & 3354 & 161 & 10862 & 14.8 & 1.0 (reference) & \\
\hline $60-89$ & 7687 & 870 & 26338 & 33.0 & 1.09 (0.91 to 1.30$)$ & 0.36 \\
\hline $45-59$ & 2962 & 620 & 10889 & 56.9 & $1.20(0.99$ to 1.46$)$ & 0.06 \\
\hline $30-44$ & 932 & 303 & 2993 & 101.2 & 1.62 (1.31 to 2.00$)$ & $<0.01$ \\
\hline $15-29$ & 263 & 99 & 714 & 138.6 & 2.12 (1.62 to 2.78$)$ & $<0.01$ \\
\hline$<15$ & 47 & 16 & 136 & 117.8 & 2.02 (1.19 to 3.42$)$ & 0.01 \\
\hline Missing & 1587 & 197 & 5418 & 36.4 & 1.20 (0.96 to 1.50$)$ & 0.11 \\
\hline \multicolumn{7}{|l|}{ Medication use } \\
\hline ACEI/ARB & 11494 & 1607 & 39075 & 41.1 & 0.95 (0.86 to 1.06$)$ & 0.37 \\
\hline MRA & 493 & 148 & 1189 & 124.4 & 1.35 (1.11 to 1.63$)$ & $<0.01$ \\
\hline
\end{tabular}

${ }^{*}$ Adjusted for all other variables in the table.

†In the year before study entry.

ACEI, ACE inhibitor; ARB, angiotensin receptor blocker; BMI, body mass index; COPD, chronic obstructive pulmonary disease;

DKD, diabetic kidney disease; eGFR, estimated glomerular filtration rate; GP, general practitioner; IHD, ischemic heart disease; MRA,

mineralocorticoid receptor antagonist.

in this BMI category did not reveal any particular trend (online supplemental table 15). Associations between BMI category and stage 5 CKD/ESRD did not seem to differ between the sexes (online supplemental tables 16 and 17) and remained virtually unchanged after further adjustment for history of anemia (online supplemental table 18). The largest effect size for development of stage $5 \mathrm{CKD} / \mathrm{ESRD}$ was renal function $<60 \mathrm{~mL} / \mathrm{min} / 1.73 \mathrm{~m}^{2}$ : adjusted HRs (95\% CIs) using Cox proportional hazard regression modeling were 5.46 (2.52 to 11.84 ) for eGFR
$45-59 \mathrm{~mL} / \mathrm{min} / 1.73 \mathrm{~m}^{2}, 8.06$ (3.55 to 18.29 ) for eGFR $30-44 \mathrm{~mL} / \mathrm{min} / 1.73 \mathrm{~m}^{2}$, and 25.82 (11.09 to 60.11 ) for eGFR $15-29 \mathrm{~mL} / \mathrm{min} / 1.73 \mathrm{~m}^{2}$. Time between diabetes diagnosis and DKD diagnosis was not found to be associated with the risk of stage $5 \mathrm{CKD} / \mathrm{ESRD}$.

\section{DISCUSSION}

In this large population-based study, we found that the risk of death among people with type 2 diabetes and DKD 
Table 2 All-cause mortality rates per 1000 person-years among people with type 2 diabetes in the DKD and comparison cohorts, and associated HRs (95\% Cls; DKD vs comparison)

\begin{tabular}{|c|c|c|c|c|c|c|}
\hline Subgroup & $\mathbf{N}$ & Deaths & Person-years & $\begin{array}{l}\text { Mortality rate per } \\
1000 \text { person-years }\end{array}$ & $\begin{array}{l}\text { Adjusted HR* } \\
(95 \% \mathrm{Cl})\end{array}$ & $P$ value \\
\hline \multicolumn{7}{|l|}{ Age $<65$ years } \\
\hline Matched comparison cohort & 3267 & 103 & 1905 & 8.65 & 1.0 (reference) & \\
\hline DKD cohort & 3267 & 249 & 12168 & 20.46 & 1.83 (1.41 to 2.38$)$ & $<0.01$ \\
\hline \multicolumn{7}{|l|}{ Age $\geq 65$ years } \\
\hline Matched comparison cohort & 5149 & 698 & 16317 & 42.78 & 1.0 (reference) & \\
\hline DKD cohort & 5149 & 1216 & 16960 & 71.70 & 1.44 (1.30 to 1.60$)$ & $<0.01$ \\
\hline \multicolumn{7}{|l|}{ Male } \\
\hline Matched comparison cohort & 5251 & 503 & 17391 & 28.92 & 1.0 (reference) & \\
\hline DKD cohort & 5251 & 905 & 18088 & 50.03 & 1.39 (1.23 to 1.57$)$ & $<0.01$ \\
\hline \multicolumn{7}{|l|}{ Female } \\
\hline Matched cohort subcohort & 3165 & 298 & 10831 & 27.51 & 1.0 (reference) & \\
\hline DKD cohort & 3165 & 560 & 11040 & 50.73 & 1.68 (1.44 to 1.97$)$ & $<0.01$ \\
\hline
\end{tabular}

${ }^{*}$ Adjusted for all the variables in table 1 .

DKD, diabetic kidney disease.

remains extremely high, with 1 death among every 20 people each year. This mortality rate was $50 \%$ higher than the rate among people with type 2 diabetes without DKD at the start of follow-up after adjusting for other factors and was not significantly different between the sexes; the excess of mortality was slightly greater in younger age groups. Strong evidence was also found for a $60 \%$ higher rate of CV death among people with type 2 diabetes and DKD compared with those without DKD.

Other population-based studies have similarly shown that DKD confers a substantially higher mortality risk among people with diabetes, ${ }^{8}{ }^{9} 1819$ and the annual mortality rate of 64.1 per 1000 per year individuals seen in our study is similar to that reported by Ang $e a^{19}$ among over 3000 people with DKD in Singapore. Reduced renal function at baseline was an independent risk factor for both CV mortality and ESRD, consistent with previous findings for $\mathrm{CV}$ mortality ${ }^{20-22}$ and $\mathrm{ESRD}^{20}$ among people with diabetes ${ }^{20} 212324$ or specifically with DKD. ${ }^{9}$ We did not find reduced renal function to be associated with increased all-cause mortality as reported by others. ${ }^{9} 20-24$ In line with reports from among general populations, ${ }^{25} 26$ we found high material deprivation to be associated with elevated risks of CVD mortality and ESRD in our type 2 diabetes cohort, yet no association was seen between material deprivation and all-cause mortality. Several factors previously reported to be independently associated with higher risks of all-cause mortality were confirmed in our study, including older age, ${ }^{923} 24$ smoking, ${ }^{23} 2427$ CVD risk factors, ${ }^{23}$ cerebrovascular disease, ${ }^{23}$ being underweight, ${ }^{24}$ pancreatic disease, ${ }^{28}$ and liver disorders. ${ }^{29}$ Similarly, we confirmed previous reports that being female ${ }^{24}$ or being overweight ${ }^{27}$ was associated with lower risk of death. Age and other traditional CVD risk factors were also associated with a higher risk of CV mortality, while cancer was associated with elevated ESRD risk. We found no evidence for associations between smoking or hyperlipidemia and DKD, and other findings on this topic have been mixed..$^{30}$ We found that among patients with DKD, being overweight was associated with slower progression to ESRD, and that this was seen for both sexes and across BMI categories. However, this finding should be interpreted with caution because the general health status of these overweight patients with diabetes and compromised renal function might have been quite different from those who were not overweight. Under these circumstances, adjustment for baseline factors might not have been able to fully account for these differences. The results of the Fine and Gray analysis, with decreasing statistical significance and magnitude of the association, seem to confirm this. Although quality of glycemic control was not associated with either all-cause/CV mortality or ESRD, use of glucagon-like peptide-1 (GLP-1) agonists was associated with a $50 \%$ reduced risk of death.

Our population-based sample of people with DKD and a matched non-DKD comparison cohort from a data source representative of the UK population means our findings have good generalizability. The large sample size enabled calculation of precise incidence rates and relative risk estimates, although less powered for ESRD analyses. We explored of a wide range of potential risk factors for mortality and ESRD, including demographics, comorbidities, medications, healthcare use and lifestyle factors. Our study also has its limitations. First, some people may have been missed from inclusion in the DKD cohort because we identified DKD using KDOQI clinical criteria from recorded test results performed during routine clinical practice, yet not everyone with diabetes will necessarily have been tested. Also, KDOQI criteria for DKD identification has its shortcomings because kidney 
Table 3 CV mortality rates per 1000 person-years among the DKD and comparison cohorts, and associated HRs (95\% Cls; DKD vs comparison)

\begin{tabular}{|c|c|c|c|c|c|c|}
\hline Variable & CV deaths & $\begin{array}{l}\text { Incidence } \\
\text { rate per } 1000 \\
\text { person-years }\end{array}$ & $\begin{array}{l}\text { HR }^{\star} \\
(95 \% \mathrm{Cl})\end{array}$ & $P$ value & $\begin{array}{l}\mathrm{SHR}^{*} \\
(95 \% \mathrm{Cl})\end{array}$ & $P$ value \\
\hline \multicolumn{7}{|l|}{ Subcohort } \\
\hline Matched comparison & 103 & 3.65 & 1.0 (reference) & & 1.0 (reference) & \\
\hline DKD & 233 & 8.00 & 1.60 (1.24 to 2.05$)$ & $<0.01$ & $1.56(1.21$ to 2.00$)$ & $<0.01$ \\
\hline \multicolumn{7}{|l|}{ Age (years) } \\
\hline$<40$ & 0 & - & - & - & - & - \\
\hline $40-49$ & 4 & 0.85 & 1.0 (reference) & & 1.0 (reference) & \\
\hline $50-64$ & 48 & 2.62 & $2.29(0.82$ to 6.42$)$ & 0.12 & 2.18 (0.78 to 6.05$)$ & 0.14 \\
\hline $65-74$ & 102 & 5.20 & $3.68(1.31$ to 10.30$)$ & 0.01 & $3.32(1.19$ to 9.24$)$ & 0.02 \\
\hline $75-89$ & 182 & 13.34 & 7.78 (2.75 to 21.99$)$ & $<0.01$ & 6.24 (2.26 to 17.23$)$ & $<0.01$ \\
\hline \multicolumn{7}{|l|}{ Sex } \\
\hline Male & 213 & 6.00 & 1.0 (reference) & & 1.0 (reference) & \\
\hline Female & 123 & 5.62 & 0.89 (0.69 to 1.13$)$ & 0.33 & $0.91(0.71$ to 1.15$)$ & 0.42 \\
\hline \multicolumn{7}{|l|}{ Smoking } \\
\hline Non-smoker & 88 & 4.42 & 1.0 (reference) & & 1.0 (reference) & \\
\hline Smoker & 38 & 5.08 & 1.31 (0.88 to 1.96$)$ & 0.19 & 1.18 (0.79 to 1.77$)$ & 0.42 \\
\hline Ex-smoker & 164 & 5.85 & 0.95 (0.72 to 1.25$)$ & 0.72 & $0.98(0.74$ to 1.30$)$ & 0.89 \\
\hline Missing & 46 & 24.20 & 4.98 (3.40 to 7.30$)$ & $<0.01$ & 2.14 (1.47 to 3.13$)$ & $<0.01$ \\
\hline \multicolumn{7}{|l|}{ Alcohol (units/week) } \\
\hline Non-drinker & 72 & 5.83 & 1.0 (reference) & & 1.0 (reference) & \\
\hline $1-2$ & 108 & 5.96 & $1.09(0.80$ to 1.48$)$ & 0.59 & $1.11(0.82$ to 1.52$)$ & 0.50 \\
\hline $3-15$ & 89 & 6.05 & 1.25 (0.90 to 1.73$)$ & 0.19 & $1.22(0.87$ to 1.70$)$ & 0.25 \\
\hline $16-24$ & 16 & 4.98 & 1.12 (0.64 to 1.97$)$ & 0.69 & 1.13 (0.63 to 2.01$)$ & 0.69 \\
\hline$\geq 25$ & 19 & 5.11 & 1.18 (0.69 to 2.00$)$ & 0.54 & $1.13(0.66$ to 1.93$)$ & 0.65 \\
\hline Missing & 32 & 6.08 & $1.18(0.77$ to 1.80$)$ & 0.44 & $1.14(0.74$ to 1.76$)$ & 0.56 \\
\hline \multicolumn{7}{|l|}{ BMI $\left(\mathrm{kg} / \mathrm{m}^{2}\right)$} \\
\hline$<20$ & 10 & 13.70 & 1.55 (0.77 to 3.09$)$ & 0.22 & 1.37 (0.67 to 2.82$)$ & 0.39 \\
\hline $20-24$ & 48 & 6.59 & 1.0 (reference) & & 1.0 (reference) & \\
\hline $25-29$ & 121 & 6.16 & 1.09 (0.78 to 1.54$)$ & 0.61 & $1.20(0.85$ to 1.70$)$ & 0.30 \\
\hline$\geq 30$ & 153 & 5.22 & 1.13 (0.80 to 1.59$)$ & 0.49 & 1.25 (0.88 to 1.78$)$ & 0.22 \\
\hline Missing & 4 & 10.98 & 1.84 (0.65 to 5.19$)$ & 0.25 & $1.47(0.50$ to 4.39$)$ & 0.48 \\
\hline \multicolumn{7}{|l|}{ Townsend index } \\
\hline $\begin{array}{l}\text { 1st quintile (least } \\
\text { deprivation) }\end{array}$ & 51 & 4.43 & 1.0 (reference) & & 1.0 (reference) & \\
\hline 2nd quintile & 71 & 6.13 & $1.28(0.89$ to 1.83$)$ & 0.19 & $1.28(0.89$ to 1.84$)$ & 0.19 \\
\hline 3rd quintile & 74 & 6.07 & 1.32 (0.92 to 1.89$)$ & 0.13 & $1.30(0.90$ to 1.88$)$ & 0.16 \\
\hline 4th quintile & 73 & 6.19 & 1.31 (0.91 to 1.89$)$ & 0.15 & $1.32(0.92$ to 1.91$)$ & 0.13 \\
\hline $\begin{array}{l}\text { 5th quintile (most } \\
\text { deprivation) }\end{array}$ & 61 & 6.90 & 1.48 (1.01 to 2.18$)$ & 0.04 & 1.50 (1.02 to 2.21$)$ & 0.04 \\
\hline Missing & 6 & 4.21 & 0.84 (0.36 to 1.98$)$ & 0.69 & 0.84 (0.35 to 1.97$)$ & 0.68 \\
\hline \multicolumn{7}{|l|}{ Glycemic control quality $†$} \\
\hline Always $\leq 8 \%$ & 216 & 5.98 & 1.0 (reference) & & 1.0 (reference) & \\
\hline At some point $>8 \%$ & 85 & 6.07 & 1.27 (0.98 to 1.65$)$ & 0.07 & 1.24 (0.95 to 1.62$)$ & 0.11 \\
\hline Missing & 35 & 4.84 & 0.86 (0.59 to 1.26$)$ & 0.44 & 0.87 (0.59 to 1.27$)$ & 0.47 \\
\hline
\end{tabular}


Table 3 Continued

\begin{tabular}{|c|c|c|c|c|c|c|}
\hline Variable & CV deaths & $\begin{array}{l}\text { Incidence } \\
\text { rate per } 1000 \\
\text { person-years }\end{array}$ & $\begin{array}{l}\text { HR* }^{*} \\
(95 \% \mathrm{Cl})\end{array}$ & $P$ value & $\begin{array}{l}\text { SHR* }^{*} \\
(95 \% \mathrm{Cl})\end{array}$ & $P$ value \\
\hline \multicolumn{7}{|l|}{ Comorbidities } \\
\hline Hypertension & 266 & 6.79 & 1.36 (1.02 to 1.81$)$ & 0.03 & 1.36 (1.03 to 1.81$)$ & 0.03 \\
\hline Hyperlipemia & 120 & 6.26 & 1.00 (0.79 to 1.25$)$ & 0.97 & 1.02 (0.81 to 1.29$)$ & 0.86 \\
\hline Heart failure & 68 & 26.43 & $1.56(1.11$ to 2.19$)$ & 0.01 & 1.46 (1.00 to 2.14$)$ & 0.05 \\
\hline IHD & 124 & 10.89 & 1.30 (1.02 to 1.65$)$ & 0.04 & 1.26 (0.97 to 1.62$)$ & 0.08 \\
\hline Atrial fibrillation & 100 & 21.59 & 1.85 (1.40 to 2.45$)$ & $<0.01$ & 1.79 (1.33 to 2.41$)$ & $<0.01$ \\
\hline Cerebrovascular disease & 69 & 14.21 & 1.55 (1.18 to 2.05$)$ & $<0.01$ & 1.51 (1.14 to 2.00$)$ & $<0.01$ \\
\hline COPD & 52 & 12.53 & 1.54 (1.13 to 2.11$)$ & 0.01 & $1.26(0.91$ to 1.74$)$ & 0.17 \\
\hline Peptic ulcer disease & 37 & 9.20 & 1.06 (0.75 to 1.51$)$ & 0.73 & 1.08 (0.75 to 1.55$)$ & 0.70 \\
\hline Pancreatic disease & 9 & 10.26 & 1.31 (0.66 to 2.58$)$ & 0.44 & 1.31 (0.64 to 2.70$)$ & 0.46 \\
\hline Liver disorders & 12 & 5.79 & 0.90 (0.50 to 1.62$)$ & 0.73 & 0.83 (0.46 to 1.51$)$ & 0.55 \\
\hline Cancer & 66 & 8.94 & 1.15 (0.87 to 1.52$)$ & 0.32 & 1.02 (0.76 to 1.36$)$ & 0.92 \\
\hline \multicolumn{7}{|l|}{ GP visits $†$} \\
\hline$<12$ & 40 & 2.92 & 1.0 (reference) & & 1.0 (reference) & \\
\hline $12-23$ & 135 & 4.84 & 1.40 (0.98 to 2.01$)$ & 0.07 & 1.35 (0.95 to 1.93$)$ & 0.10 \\
\hline 24-35 & 82 & 7.70 & 1.54 (1.02 to 2.31$)$ & 0.04 & 1.52 (1.00 to 2.29$)$ & 0.05 \\
\hline$\geq 36$ & 79 & 15.44 & 2.20 (1.40 to 3.47$)$ & $<0.01$ & 1.80 (1.12 to 2.89$)$ & 0.01 \\
\hline \multicolumn{7}{|l|}{ Referrals to secondary care $\dagger$} \\
\hline None & 43 & 4.63 & 1.0 (reference) & & 1.0 (reference) & \\
\hline $1-6$ & 191 & 5.42 & $1.03(0.73$ to 1.44$)$ & 0.88 & 1.03 (0.73 to 1.45$)$ & 0.87 \\
\hline$\geq 7$ & 102 & 7.94 & $0.83(0.55$ to 1.25$)$ & 0.38 & 0.83 (0.55 to 1.26$)$ & 0.38 \\
\hline$>1$ hospitalization $†$ & 94 & 10.10 & $1.23(0.94$ to 1.61$)$ & 0.14 & 1.14 (0.86 to 1.52$)$ & 0.35 \\
\hline \multicolumn{7}{|c|}{ Lowest eGFR $\left(\mathrm{mL} / \mathrm{min} / 1.73 \mathrm{~m}^{2}\right) \dagger$} \\
\hline$\geq 90$ & 16 & 1.47 & 1.0 (reference) & & 1.0 (reference) & \\
\hline $60-89$ & 130 & 4.94 & 1.57 (0.91 to 2.72) & 0.10 & 1.62 (0.93 to 2.83$)$ & 0.09 \\
\hline $45-59$ & 104 & 9.55 & 1.81 (1.02 to 3.20$)$ & 0.04 & 1.91 (1.07 to 3.42$)$ & 0.03 \\
\hline $30-44$ & 46 & 15.37 & 2.07 (1.11 to 3.87$)$ & 0.02 & 1.99 (1.04 to 3.80$)$ & 0.04 \\
\hline $15-29$ & 14 & 19.59 & 2.63 (1.22 to 5.65$)$ & 0.01 & $2.10(0.93$ to 4.72$)$ & 0.07 \\
\hline$<15$ & 0 & 0 & - & & - & \\
\hline Missing & 26 & 4.80 & 1.81 (0.94 to 3.49$)$ & 0.08 & 1.80 (0.93 to 3.49$)$ & 0.08 \\
\hline \multicolumn{7}{|l|}{ Medication use $†$} \\
\hline ACEI/ARB & 253 & 6.47 & $0.88(0.67$ to 1.16$)$ & 0.36 & 0.88 (0.67 to 1.16$)$ & 0.36 \\
\hline MRA & 39 & 32.79 & 2.10 (1.40 to 3.13$)$ & $<0.01$ & 2.07 (1.33 to 3.22$)$ & $<0.01$ \\
\hline
\end{tabular}

${ }^{*}$ Adjusted for all the other variables in the table.

†In the year before study entry.

ACEI, ACE inhibitor; ARB, angiotensin receptor blocker; BMI, body mass index; COPD, chronic obstructive pulmonary disease; CV, cardiovascular; DKD, diabetic kidney disease; eGFR, estimated glomerular filtration rate; GP, general practitioner; IHD, ischemic heart disease; MRA, mineralocorticoid receptor antagonist; SHR, subdistribution HR.

biopsy is the gold standard for differentiating DKD from other kidney disease in diabetes. Results of kidney biopsy are, if available, rarely recorded in primary care records. Additionally, evidence from the UK Prospective Diabetes Study that up to $40 \%$ of people with type 2 diabetes and reduced eGFR never develop albuminuria ${ }^{31}$ suggests that our operational definition of DKD may have missed some patients. Second, CV deaths are likely to have been underestimated because cause of death was not recorded in the majority $(>80 \%)$ of cases. Some studies have reported that CVD accounts for half of all deaths among people with type 2 diabetes, ${ }^{32}$ who are more disproportionately affected by CVD than people without diabetes. ${ }^{33}$ Third, although the majority of people with type 2 diabetes will 
Table 4 Incidence rates of stage 5 CKD/ESRD per 1000 person-years among the DKD cohort, and HRs (95\% Cls) for associations between person characteristics and risk of stage 5 CKD/ESRD

\begin{tabular}{|c|c|c|c|c|c|c|}
\hline Variable & $\mathbf{N}$ & $\begin{array}{l}\text { Incidence rate per } \\
1000 \text { person-years }\end{array}$ & Person-years & $\begin{array}{l}\text { Stage } 5 \text { CKD/ } \\
\text { ESRD }\end{array}$ & $\begin{array}{l}\mathrm{HR}^{\star} \\
(95 \% \mathrm{Cl})\end{array}$ & $\begin{array}{l}\mathrm{SHR}^{\star} \\
(95 \% \mathrm{Cl})\end{array}$ \\
\hline \multicolumn{7}{|l|}{ Age (years) } \\
\hline$<40$ & 158 & 0 & 594 & 0 & - & - \\
\hline $40-49$ & 635 & 4.16 & 2402 & 10 & 1.0 (reference) & 1.0 (reference) \\
\hline $50-64$ & 2597 & 5.10 & 9404 & 48 & 0.77 (0.38 to 1.56$)$ & 0.76 (0.36 to 1.61$)$ \\
\hline $65-74$ & 3028 & 7.71 & 10502 & 81 & $0.88(0.43$ to 1.80$)$ & 0.82 (0.38 to 1.79$)$ \\
\hline $75-89$ & 2757 & 9.45 & 7827 & 74 & 0.84 (0.40 to 1.79$)$ & 0.68 (0.30 to 1.54$)$ \\
\hline \multicolumn{7}{|l|}{ Sex } \\
\hline Male & 5744 & 6.80 & 19114 & 130 & 1.0 (reference) & 1.0 (reference) \\
\hline Female & 3431 & 7.15 & 11614 & 83 & 0.85 (0.63 to 1.16$)$ & 0.90 (0.66 to 1.23$)$ \\
\hline \multicolumn{7}{|l|}{ BMI $\left(\mathrm{kg} / \mathrm{m}^{2}\right)$} \\
\hline$<20$ & 148 & 17.75 & 394 & 7 & $1.49(0.65$ to 3.41$)$ & $1.41(0.64$ to 3.13$)$ \\
\hline $20-24$ & 1195 & 11.62 & 3614 & 42 & 1.0 (reference) & 1.0 (reference) \\
\hline $25-29$ & 2941 & 5.90 & 10005 & 59 & 0.58 (0.39 to 0.88$)$ & 0.61 (0.40 to 0.93$)$ \\
\hline$\geq 30$ & 4835 & 6.30 & 16511 & 104 & 0.64 (0.44 to 0.95$)$ & 0.68 (0.46 to 1.00$)$ \\
\hline Missing & 56 & 4.92 & 203 & 1 & 0.34 (0.05 to 2.57$)$ & 0.32 (0.05 to 2.05$)$ \\
\hline \multicolumn{7}{|l|}{ Townsend index (quintile) } \\
\hline 1st (least deprivation) & 1672 & 4.76 & 5464 & 26 & 1.0 (reference) & 1.0 (reference) \\
\hline 2nd & 1844 & 6.62 & 6044 & 40 & 1.33 (0.81 to 2.20$)$ & $1.34(0.81$ to 2.20$)$ \\
\hline $3 r d$ & 1891 & 6.55 & 6415 & 42 & 1.49 (0.91 to 2.44$)$ & 1.43 (0.87 to 2.36$)$ \\
\hline 4th & 1961 & 8.68 & 6682 & 58 & 1.95 (1.22 to 3.12$)$ & 1.88 (1.18 to 2.99$)$ \\
\hline 5th (most deprivation) & 1545 & 7.60 & 5265 & 40 & 1.76 (1.06 to 2.93$)$ & 1.71 (1.03 to 2.84$)$ \\
\hline Missing & 262 & 8.15 & 859 & 7 & 1.79 (0.77 to 4.19$)$ & 1.84 (0.80 to 4.23$)$ \\
\hline \multicolumn{7}{|l|}{ Glycemic control quality† } \\
\hline Always $\leq 8 \%$ & 5634 & 6.80 & 18819 & 128 & 1.0 (reference) & 1.0 (reference) \\
\hline At some point $>8 \%$ & 2933 & 6.51 & 9371 & 61 & 1.07 (0.76 to 1.50$)$ & 1.05 (0.76 to 1.47$)$ \\
\hline Missing & 608 & 9.46 & 2538 & 24 & 1.30 (0.82 to 2.07$)$ & 1.21 (0.75 to 1.95$)$ \\
\hline \multicolumn{7}{|l|}{ Comorbidities } \\
\hline Hypertension & 6609 & 7.49 & 22155 & 166 & 1.21 (0.85 to 1.72$)$ & $1.22(0.86$ to 1.74$)$ \\
\hline Hyperlipemia & 3154 & 5.74 & 10623 & 61 & 0.76 (0.56 to 1.03$)$ & 0.77 (0.57 to 1.04$)$ \\
\hline Heart failure & 691 & 14.30 & 1818 & 26 & 1.50 (0.93 to 2.44$)$ & 1.38 (0.86 to 2.20$)$ \\
\hline IHD & 2105 & 9.03 & 6753 & 61 & 1.17 (0.84 to 1.62$)$ & $1.14(0.82$ to 1.59$)$ \\
\hline Cancer & 1539 & 13.76 & 4287 & 59 & 1.99 (1.45 to 2.73$)$ & 1.75 (1.27 to 2.42$)$ \\
\hline \multicolumn{7}{|c|}{ Lowest eGFR $\left(\mathrm{mL} / \mathrm{min} / 1.73 \mathrm{~m}^{2}\right) \dagger$} \\
\hline$\geq 90$ & 1594 & 1.51 & 5281 & 8 & 1.0 (reference) & 1.0 (reference) \\
\hline $60-89$ & 3390 & 3.57 & 11205 & 40 & 2.19 (1.00 to 4.79$)$ & 2.22 (0.98 to 5.02$)$ \\
\hline $45-59$ & 2314 & 9.76 & 8404 & 82 & 5.46 (2.52 to 11.84$)$ & 5.59 (2.47 to 12.63$)$ \\
\hline $30-44$ & 796 & 15.68 & 2487 & 39 & 8.06 (3.55 to 18.29$)$ & 7.74 (3.30 to 18.16$)$ \\
\hline $15-29$ & 224 & 47.41 & 612 & 29 & $25.82(11.09$ to 60.11$)$ & 23.30 (9.47 to 57.31$)$ \\
\hline$<15$ & 0 & 0 & 0 & 0 & - & - \\
\hline Missing & 857 & 5.48 & 2740 & 15 & 3.92 (1.61 to 9.54$)$ & 3.88 (1.55 to 9.70$)$ \\
\hline \multicolumn{7}{|l|}{ GP visits $†$} \\
\hline$<12$ & 1615 & 3.51 & 5986 & 21 & 1.0 (reference) & 1.0 (reference) \\
\hline $12-23$ & 4085 & 6.07 & 14509 & 88 & 1.55 (0.95 to 2.53 ) & 1.54 (0.95 to 2.51) \\
\hline 24-35 & 2067 & 9.09 & 6491 & 59 & 1.97 (1.15 to 3.38$)$ & 1.90 (1.10 to 3.28$)$ \\
\hline$\geq 36$ & 1408 & 12.03 & 3742 & 45 & 2.23 (1.22 to 4.09$)$ & 1.95 (1.02 to 3.72$)$ \\
\hline
\end{tabular}

Referrals to secondary care $\dagger$ 
Table 4 Continued

\begin{tabular}{|c|c|c|c|c|c|c|}
\hline Variable & $\mathbf{N}$ & $\begin{array}{l}\text { Incidence rate per } \\
1000 \text { person-years }\end{array}$ & Person-years & $\begin{array}{l}\text { Stage } 5 \text { CKD/ } \\
\text { ESRD }\end{array}$ & $\begin{array}{l}\mathrm{HR}^{\star} \\
(95 \% \mathrm{Cl})\end{array}$ & $\begin{array}{l}\text { SHR }^{*} \\
(95 \% \mathrm{Cl})\end{array}$ \\
\hline None & 1121 & 7.50 & 4536 & 34 & 1.0 (reference) & 1.0 (reference) \\
\hline $1-6$ & 5252 & 5.93 & 18221 & 108 & 0.77 (0.51 to 1.15$)$ & $0.75(0.50$ to 1.14$)$ \\
\hline$\geq 7$ & 2802 & 8.91 & 7971 & 71 & 0.75 (0.46 to 1.21$)$ & $0.72(0.43$ to 1.20$)$ \\
\hline$>1$ hospitalization $\dagger$ & 1940 & 10.21 & 5678 & 58 & $1.13(0.80$ to 1.59$)$ & 1.09 (0.76 to 1.56$)$ \\
\hline \multicolumn{7}{|l|}{ Antidiabetic medication $\dagger$} \\
\hline None & 1719 & 5.42 & 6088 & 33 & 1.0 (reference) & 1.0 (reference) \\
\hline $\begin{array}{l}1 \text { class of non-insulin } \\
\text { glucose-lowering } \\
\text { medication }\end{array}$ & 3394 & 7.64 & 11525 & 88 & 1.80 (1.20 to 2.72$)$ & 1.82 (1.20 to 2.75$)$ \\
\hline $\begin{array}{l}2 \text { classes of non-insulin } \\
\text { glucose-lowering } \\
\text { medication }\end{array}$ & 2475 & 6.74 & 8460 & 57 & 1.66 (1.04 to 2.63 ) & 1.72 (1.07 to 2.76$)$ \\
\hline $\begin{array}{l}>2 \text { classes of non- } \\
\text { insulin glucose-lowering } \\
\text { medication }\end{array}$ & 896 & 6.36 & 2673 & 17 & 2.10 (1.11 to 3.98$)$ & 2.14 (1.14 to 4.02$)$ \\
\hline Insulin & 691 & 9.08 & 1982 & 18 & 2.00 (1.06 to 3.75$)$ & 1.96 (1.07 to 3.60$)$ \\
\hline \multicolumn{7}{|l|}{ Other medication $\dagger$} \\
\hline ACEI/ARB & 6978 & 7.28 & 23635 & 172 & 1.06 (0.73 to 1.53$)$ & $1.12(0.77$ to 1.62$)$ \\
\hline MRA & 370 & 13.75 & 873 & 12 & 0.94 (0.49 to 1.81$)$ & $0.85(0.43$ to 1.65$)$ \\
\hline \multicolumn{7}{|c|}{ Time from diabetes diagnosis to DKD (years) } \\
\hline $0-1$ & 285 & 7.13 & 1263 & 9 & 1.0 (reference) & 1.0 (reference) \\
\hline $1-2$ & 811 & 7.00 & 3428 & 24 & $0.86(0.40$ to 1.89$)$ & $0.89(0.41$ to 1.96$)$ \\
\hline $2-3$ & 1029 & 8.19 & 4520 & 37 & $0.92(0.43$ to 1.95$)$ & $0.96(0.46$ to 2.02$)$ \\
\hline $3-4$ & 1117 & 7.46 & 4559 & 34 & 0.77 (0.36 to 1.66$)$ & $0.75(0.35$ to 1.58$)$ \\
\hline $4-5$ & 1060 & 6.57 & 4110 & 27 & $0.66(0.30$ to 1.45$)$ & $0.64(0.29$ to 1.42$)$ \\
\hline$>5$ & 4873 & 6.38 & 12847 & 82 & 0.66 (0.31 to 1.38$)$ & $0.61(0.30$ to 1.25$)$ \\
\hline
\end{tabular}

${ }^{*}$ Adjusted for all the other variables in the table.

†In the year before study entry.

ACEI, ACE inhibitor; ARB, angiotensin receptor blocker; BMI, body mass index; CKD, chronic kidney disease; DKD, diabetic kidney disease; eGFR, estimated glomerular filtration rate; ESRD, end-stage renal disease; GP, general practitioner; IHD, ischemic heart disease; MRA, mineralocorticoid receptor antagonist; SHR, subdistribution HR.

have their renal function assessed regularly, the likely inclusion of some without consistent renal function testing would have led to some misclassification of renal function at baseline and during follow-up. Fourth, drug use was determined at the start of follow-up, and while this avoids finding spurious associations between chronic medication and survival when drug use is determined around the date of death, drug use may change during follow-up. Glycosylated hemoglobin measurements may also have changed during follow-up. Finally, we were unable to explore ethnicity, family history, physical activity or dietary intake as potential risk factors as this information is not generally recorded in the database.

CVD is the main competing cause of death to ESRD among people with diabetes, thereby highlighting the need for treatments that prevent both adverse CV events and DKD progression. So far, the cornerstone of treatment for DKD management and the prevention of CVD mortality has been control of traditional CVD risk factors, using established therapies such as ACE inhibitors and angiotensin receptor blockers that reduce progression of the disease through lowering blood pressure. ${ }^{34-36}$ More recently, two glucose-lowering therapies-sodiumglucose transport protein 2 (SGLT2) inhibitors and GLP-1 receptor agonists-have been shown to reduce both CVD risk (mainly heart failure) and DKD progression. Currently, evidence is stronger for SGLT2 as a cardiorenal reducing class of drugs, including among people with reduced renal function. ${ }^{37}$ We were unable to perform a meaningful analysis of SGLT2 inhibitors because relatively few people used these drugs during the current follow-up period. MRAs are another class of drugs being investigated as a possible treatment for DKD. There is some evidence that they decrease the risk of $\mathrm{CV}$ events and sudden death in people with reduced $\mathrm{eGFR}^{38}$ and might therefore have similar beneficial effects in people with DKD. In our study, however, use of MRAs was associated with a twofold higher risk of CV mortality, and a $35 \%$ increased risk of all-cause mortality, and no association was seen with ESRD risk. MRAs with 
greater selectivity and receptor affinity to those used in practice are currently being investigated for their effects on reducing clinically important $\mathrm{CV}$ and renal outcomes in people with DKD. ${ }^{39}$

Our results strongly support continued focus and support to people with type 2 diabetes and DKD in optimizing treatment in clinical practice and continual review of guidelines. The prevalence of DKD is expected to increase alongside increasing prevalence of diabetes, ${ }^{40}$ and use of renal replacement therapy is projected to increase dramatically, with an estimated 4.3 million people needing this treatment worldwide by $2030 .{ }^{41}$ Considering the high mortality rates among people with $\mathrm{DKD}$, the condition remains a growing public health problem, and there is an explicit need for newer effective treatments to improve cardiorenal outcomes in these people. The independent risk factors for mortality and ESRD identified in this study will help identify people with type 2 diabetes at most risk of death and progression of kidney disease and help to direct effective management strategies.

Acknowledgements We thank Susan Bromley, EpiMed Communications (Abingdon, Oxford, UK), for medical writing assistance funded by Bayer in accordance with Good Publication Practice.

Contributors Study concept—DV, AG-P and LGR. Study design-AG-P, MS, LGR and DV. Data extraction and analysis-AG-P. Interpretation of the data-all authors. Review of manuscript drafts-all authors. Final approval of the manuscript for publication-all authors.

Funding This study was funded by Bayer (grant number N/A).

Disclaimer The sponsor has no role in the study design, the collection, analysis and interpretation of data, writing the report or the decision to submit the report for publication, apart from in the form of salary paid to DV.

Competing interests DV is a full-time employee of Bayer Hispania, Barcelona, Spain. LGR, AG-P and MS work for CEIFE (Madrid, Spain), which has received research funding from Bayer. LGR has also received honoraria for serving on advisory boards for Bayer. ML has received research grants from AstraZeneca, DexCom and Novo Nordisk and been consultant for AstraZeneca, DexCom, Eli Lilly, MSD and Novo Nordisk.

Patient consent for publication Not required.

Ethics approval The study protocol was approved by the Independent Scientific Research Committee for IMRD-UK (reference number: SRC-16THIN100). Data collection for IMRD-UK was approved by the South East Multicentre Research Ethics Committee in 2003 and individual studies using IMRD-UK data do not require separate ethical approval if only anonymized data are used.

Provenance and peer review Not commissioned; externally peer reviewed.

Data availability statement Data are available upon reasonable request. Data are available from the corresponding author upon reasonable request.

Supplemental material This content has been supplied by the author(s). It has not been vetted by BMJ Publishing Group Limited (BMJ) and may not have been peer-reviewed. Any opinions or recommendations discussed are solely those of the author(s) and are not endorsed by BMJ. BMJ disclaims all liability and responsibility arising from any reliance placed on the content. Where the content includes any translated material, BMJ does not warrant the accuracy and reliability of the translations (including but not limited to local regulations, clinical guidelines, terminology, drug names and drug dosages), and is not responsible for any error and/or omissions arising from translation and adaptation or otherwise.

Open access This is an open access article distributed in accordance with the Creative Commons Attribution Non Commercial (CC BY-NC 4.0) license, which permits others to distribute, remix, adapt, build upon this work non-commercially, and license their derivative works on different terms, provided the original work is properly cited, appropriate credit is given, any changes made indicated, and the use is non-commercial. See: http://creativecommons.org/licenses/by-nc/4.0/.

ORCID iD

Antonio González-Pérez http://orcid.org/0000-0001-9771-5982

\section{REFERENCES}

1 Saeedi P, Petersohn I, Salpea P, et al. Global and regional diabetes prevalence estimates for 2019 and projections for 2030 and 2045: Results from the International Diabetes Federation Diabetes Atlas, $9^{\text {th }}$ edition. Diabetes Res Clin Pract 2019;157:107843.

2 Alicic RZ, Rooney MT, Tuttle KR. Diabetic kidney disease. Clin J Am Soc Nephrol 2017;12:2032-45.

3 Yee J. Diabetic kidney disease: chronic kidney disease and diabetes. Diabetes Spectrum 2008;21:8-10.

4 Kähm K, Laxy M, Schneider U, et al. Health care costs associated with incident complications in patients with type 2 diabetes in Germany. Diabetes Care 2018;41:971-8.

5 Vupputuri S, Kimes TM, Calloway MO, et al. The economic burden of progressive chronic kidney disease among patients with type 2 diabetes. J Diabetes Complications 2014;28:10-16.

6 Bakris GL. Update on reducing the development of diabetic kidney disease and cardiovascular death in diabetes. Kidney Int Suppl 2018;8:1.

7 Amp. Diabetic kidney disease: what does the next era hold? Lancet Diabetes Endocrinol 2015;3:665.

8 Afkarian M, Sachs MC, Kestenbaum B, et al. Kidney disease and increased mortality risk in type 2 diabetes. J Am Soc Nephrol 2013;24:302-8.

9 Zhao Z, Huo L, Wang L, et al. Survival of Chinese people with type 2 diabetes and diabetic kidney disease: a cohort of 12 -year follow-up. BMC Public Health 2019;19:1498.

10 Yokoyama H, Araki S-I, Kawai K, et al. The prognosis of patients with type 2 diabetes and Nonalbuminuric diabetic kidney disease is not always poor: implication of the effects of coexisting macrovascular complications (JDDM 54). Diabetes Care 2020;43:1102-10.

11 Harding JL, Pavkov ME, Magliano DJ, et al. Global trends in diabetes complications: a review of current evidence. Diabetologia 2019;62:3-16.

12 Gregg EW, Li Y, Wang J. Changes in diabetes-related complications in the United States, 1990-2010. New England Journal of Medicine 2014;370:1514-23.

13 Rocha NA, McCullough PA. Cardiovascular outcomes in diabetic kidney disease: insights from recent clinical trials. Kidney Int Suppl 2018;8:8-17.

14 González-Pérez A, Saéz ME, Vizcaya D, et al. Impact of chronic kidney disease definition on assessment of its incidence and risk factors in patients with newly diagnosed type 1 and type 2 diabetes in the UK: a cohort study using primary care data from the United Kingdom. Prim Care Diabetes 2020;14:381-7.

15 National Kidney Foundation. KDOQI clinical practice guideline for diabetes and CKD: 2012 update. Am J Kidney Dis 2012;60:850-86.

16 Townsend P, Phillimore P, Beattie A. Health and deprivation: inequality and the North. London, 1988.

17 Fine JP, Gray RJ. A proportional hazards model for the Subdistribution of a competing risk. J Am Stat Assoc 1999;94:496-509.

18 Wen CP, Chang CH, Tsai MK, et al. Diabetes with early kidney involvement may shorten life expectancy by 16 years. Kidney Int 2017:92:388-96

19 Ang YG, Heng BH, Saxena N, et al. Annual all-cause mortality rate for patients with diabetic kidney disease in Singapore. J Clin Trans/ Endocrinol 2016;4:1-6.

20 Fox CS, Matsushita K, Woodward M, et al. Associations of kidney disease measures with mortality and end-stage renal disease in individuals with and without diabetes: a meta-analysis. Lancet 2012;380:1662-73

21 Svensson MK, Cederholm J, Eliasson B, et al. Albuminuria and renal function as predictors of cardiovascular events and mortality in a general population of patients with type 2 diabetes: a nationwide observational study from the Swedish national diabetes register. Diab Vasc Dis Res 2013;10:520-9.

22 Bo S, Ciccone G, Rosato R, et al. Renal damage in patients with type 2 diabetes: a strong predictor of mortality. Diabet Med 2005;22:258-65.

23 Cea Soriano L, Johansson S, Stefansson B, et al. Cardiovascular events and all-cause mortality in a cohort of 57,946 patients with type 2 diabetes: associations with renal function and cardiovascular risk factors. Cardiovasc Diabetol 2015;14:38. 
24 McEwen LN, Kim C, Karter AJ. Risk factors for mortality among patients with diabetes. Diabetes Care2007;30:1736-41.

25 Ramsay SE, Morris RW, Whincup PH, et al. The influence of neighbourhood-level socioeconomic deprivation on cardiovascular disease mortality in older age: longitudinal multilevel analyses from a cohort of older British men. J Epidemiol Community Health 2015;69:1224-31.

26 Akrawi DS, Li X, Sundquist J, et al. End stage renal disease risk and neighbourhood deprivation: a nationwide cohort study in Sweden. Eur J Intern Med 2014;25:853-9.

27 Afsharian S, Akbarpour S, Abdi H, et al. Risk factors for cardiovascular disease and mortality events in adults with type 2 diabetes - a 10-year follow-up: Tehran Lipid and Glucose Study. Diabetes Metab Res Rev 2016;32:596-606.

28 Bang UC, Benfield T, Hyldstrup L, et al. Mortality, cancer, and comorbidities associated with chronic pancreatitis: a Danish nationwide matched-cohort study. Gastroenterology 2014;146:989-94.

29 Fleming KM, Aithal GP, Card TR, et al. All-Cause mortality in people with cirrhosis compared with the general population: a populationbased cohort study. Liver Int 2012;32:79-84.

30 Radcliffe NJ, Seah J-M, Clarke M, et al. Clinical predictive factors in diabetic kidney disease progression. J Diabetes Investig 2017;8:6-18.

31 Retnakaran R, Cull CA, Thorne KI, et al. Risk factors for renal dysfunction in type 2 diabetes: U.K. prospective diabetes study 74 . Diabetes 2006;55:1832-9.

32 White WB, Kupfer S, Zannad F, et al. Cardiovascular mortality in patients with type 2 diabetes and recent acute coronary syndromes from the examine trial. Diabetes Care 2016;39:1267-73.
33 Martín-Timón I, Sevillano-Collantes C, Segura-Galindo A, et al. Type 2 diabetes and cardiovascular disease: have all risk factors the same strength? World J Diabetes 2014;5:444-70.

34 Brenner BM, Cooper ME, de Zeeuw D, et al. Effects of losartan on renal and cardiovascular outcomes in patients with type 2 diabetes and nephropathy. N Engl J Med 2001;345:861-9.

35 Lewis EJ, Hunsicker LG, Bain RP, et al. The effect of angiotensinconverting-enzyme inhibition on diabetic nephropathy. The Collaborative Study Group. N Engl J Med 1993;329:1456-62.

36 Lewis EJ, Hunsicker LG, Clarke WR, et al. Renoprotective effect of the angiotensin-receptor antagonist irbesartan in patients with nephropathy due to type 2 diabetes. $N$ Engl J Med 2001;345:851-60.

37 Bakris GL. Major advancements in slowing diabetic kidney disease progression: focus on SGLT2 inhibitors. Am J Kidney Dis 2019;74:573-5.

38 Epstein M. Reduction of cardiovascular risk in chronic kidney disease by mineralocorticoid receptor antagonism. Lancet Diabetes Endocrinol 2015;3:993-1003.

39 Ruilope LM, Agarwal R, Anker SD, et al. Design and baseline characteristics of the Finerenone in reducing cardiovascular mortality and morbidity in diabetic kidney disease trial. Am J Nephrol 2019;50:345-56.

40 Harjutsalo V, Groop P-H. Epidemiology and risk factors for diabetic kidney disease. Adv Chronic Kidney Dis 2014;21:260-6.

41 Liyanage T, Ninomiya T, Jha V, et al. Worldwide access to treatment for end-stage kidney disease: a systematic review. Lancet 2015;385:1975-82. 